Uprety, Laya Prasad

1986

Fodder Situation : An Ecological-Anthropological Study of Machhegaon, Nepal. HMG-USAID-GTZ IDRC FORD- Winrock Project, Food and Agricultural Sector in Nepal.

Willan, R.C.M.

1976

Forestry in Nepal. Kathmandu

World Bank 1979

Nepal Development Performance and Prospects. Washington, D.C.

World Bank 1981
Staff Appraisal Report of the Hill Food Production Project. Washington, D.C.

\section{GENDER ROLES AND ACTIVITIES AMONG THE RURAL POOR HOUSEHOLDS: CASE STUDIES FROM HILL VILLAGES}

\section{Binod Pokharel ${ }^{*}$}

Biologically, human societies are stratified into men and women dichotomies. All the known societies are unequally distributed. In small food producing societies, the inequality is limited to dyadic and non-categorical prestige bases (Pathy, 1987). There is some sort of identified division of labour between male and female in every kind of society. But, Marx stated that every form of society presupposes some rudimentry division of labour. Likewise, Mair (1999) views that the biological division of human into male and female is the basis of the most elementary social stratification everywhere. The division of labour means the fact that women bear and suckle children, and are tied to the domestic sphere for much of their lives. Wolf considers social inequality not as phenomena sui generis but as an accompaniment of the working out of determinental modes of production (quoted by Pathy, 1987).

After 1990s, the gender relationship between male and female has emerged as one of the major issues in Nepal. This issue draws the attentions of scholars, professionals, politicians and public and policy makers. Gender is defined as socially and culturally constructed accepted behaviours and relations between male and female. Behaviours and relations are structured in the society. In other words, most of the behaviours and relations are deeply rooted in social, cultural, political, economic and religious frameworks. In some traditional societies, the gender roles are more rigid than in urban and industrial societies. The

\footnotetext{
- Mr. Binod Pokharel is the Lecturer in Anthropology at the Central Department of Sociology and Anthropology, Tribhuvan University, Kirtipur, Kathmandu.
} 
gender roles also vary between and among the classes, castes and ethnic groups.

Gender is a new paradigm but it is deeply rooted in the women movement and feminist movement of 1950s. In this regards, Lorber(1994) states:

The concept of gender, however, has been theoretically grounded in sexuality and procreation. This conceptualization undermines the feminist focus on the relational aspect of women's and men's social status and the political aspects of gender inequality. She argues that gender inequality is located solely in the structured of gendered social practices and institutions. Procreation and sexuality are constructed as conditions of subordination within the social institution of gender, the social institution of gender is not built on procreation and sexuality. Human sexual reproduction is universal, but gender inequality is not. The gender status of women affects the social construction of sexuality, fertility, pregnancy, childbirth and parenting not the other way grounded.....

The history of women movement is not very old. Early women movement and feminist thought paid little attention on socially constructed differences between male and female. After 1970 s it took a momentum as a social issue. Several theories and empirical studies have been propounded on gender relations, equity and inequality after 1970s. The past literature on gender widely covered the various aspects of gender and inequality. Here attempt has been made to review some of them. Gender is not biological concept but this ideology is highly influenced by feminist paradigm. Feminist paradigm emerged form the radical thought of the 1960s (Keller, et.al,, 1996). Judith (1994) notes that gendered people emerged not from physical or sexual orientation but from the exigencies of the social order, mostly from the need for a reliable division of the work of food production and the social reproduction of new members.

Mair (1999) states that in those societies where the economy is one of subsistence production, that is, people get their food and other needs by their own labour from their immediate environment, large share of the work of agriculture falls on women. Murdock notes that biological differences between men and women form the basis of sexual division of labour in the society. However, he does not suggest that men and women are directed by genetically based predispositions to adopt their particular roles (cited by Haralumbus, 1997). Mair (1999) views that men's task's are those that call for extra physical strength and ability and that take them away from home for warfare, hunting, herding cattle, sea fishing, etc. Likewise, Lee suggests that hunter gatherers typically get their food more from hunting and that women contribute more than men to subsistence (cited by Ember et, al., 1993).

The neoclassical economists view that economic-man postulates a single notion of rationality. This rationality implies that persons are constructed as individuals who are self-seeking, they are maximizers and calculating agents (Kaplagam, 1994). Feminist economics challenges the conceptualization of the gender division of labour in neo-classical micro-economics, as the outcome of free choices of economic agents specializing according to thei0r innate comparative advantages (Evans cited by Miller et al., 1998). Marx viewed that social relations are governed by laws which are specific to each mode of production, and that the mode of production is the primary determinant of inequality (cited by Pathy, 1987). Kalpagm (1994) notes that the basic Marxist paradigm has been more useful incorporating gender analytically, though this exercise is far from complete, and despite all the difficulties is far from complete, and despite all the difficulties faced with regard to the hairsplitting debates on the political implication often engaged in by dogmatic Marxists. Almost all Marxists assumed that property as main source in creating inequality. For functionalist inequality is indispensable for the maintenance of social structure. Individuals lie on different social strarta as per their ability and capacity. Therefore, social stratification is imperative and valuable to any social system (Parsons, Davis More quoted by Pathy, 1987). Dahrendorf and Bottomore severely criticized the functionalist approach for over emphasizing consensus and considering stratification as universal and permanent. 
Lorber (1994) observes that gender roles are changing today. Fathers are taking care of little children. Girls and boys are wearing unisex clothing and getting the same education. Women and men are doing at the same jobs. Although many traditional social groups are quite strict about maintaining gender differences, in other social groups, they seem to be blurring.

Slayter et. al (1993) state that in Africa, Asia and Latin America suggests the burdens of the destruction of natural resources falls most heavily on women in poor households who must struggle to survive.

Seddon (1995) points out that in Nepal, women play a full and active role in the domestic economy. In some ethnic groups and social classes, their roles in the economy goes beyond the domestic sphere as when Thakali women are involved in the hotel and catering business, or when educated Gurung women have positions in the private and public sectors, or when women from laboring households and from the so called occupational castes work as field labourers or porters for others. Acharya and Bennett (1981) studied the status of women in Nepal. They noted that women in the more orthodox Hindu communities who are largely confined to domestic and subsistence production display a much less significant role in major household economy decision than those in the TibetoBurman communities where women participate actively in the market economy. Strishakti (1995) observes that men are predominantly the ones who interact with the outside world, while women's major sphere of operation is within the households. It is said that Nepali girls and women work for more than boys and men, spending 25 percent to 50 percent more time on households tasks, economic and agricultural activities.

Past literature on gender focused on various aspects of male-female relations on the basis of theoretical paradigm and some selected indicators. Both theory and literature gave little attention on class based gender relations. In Nepalese context, we can categorize women into several strata on the basis of their general characteristics such as rural and urban women, literate and illiterate women, caste and ethnic women, rich and poor women and so on. In urban area of the country, women no longer devote most of their productive years in household chores. The social relations of male and female in gradually changing in the urban areas. The past literature also focused on the relations of subordination and domination between male and female. They also considered the females as a homogenous group and highlights similar capacities, vulnerabilities, needs group and wower, women can be stratied into several starta on the basis of their socio-economic characteristics, eg. rural and urban, educated and uneducated, rich and poor, powerful and powerless etc. High class and urban elite women have more access to power, politics, economy and elite women social privileges than poor rural-based women. There is the relations of subordination and domination between high class women and poor women. In Nepal for last ten years, most of the women's development activities have been implemented between and among the urban elite women than rural poor women. We have several examples of the countries in South Asia ruled by women. However, the position of women ruled countries is the same as male in the ruled countries. In class-based society, the power is exercised by a particular class group and fulfil the needs of one's own class, not whole mass of the people. In Nepalese context too, number of high class or elite class women activists are working in the field of gender, advocacy, social work, politics, etc. Most of them have been holding better position in national and international organizations. These women have better position than general people. Here, my argument is that we should consider the class position of individual to analyse the gender. Because most of the male female relations are highly associated with class position of the society.

\section{The Study Area and Research Methods}

This article is based on an earlier field study conducted in late 1996 and early 1997. Three VDCs (Amarpur, Nagi and Panchami) of Panchothar district were selected for the study. The study areas were heterogeneous in terms of caste, class and ethnicity. More than sixteen caste and ethnic groups were noted during the field visit. The dominant group was Limbu followed 
by Brahmin, Chhetry, Rai, Tamang, Newar etc. All nine wards of Panchami and five wards from Nagi and Amarpur VDCs were choosen for the study. The total number of households of the sample wards was 2742 . Among them 776 households were the rural poor households. The total population of the rural poor was 4239 of which 2097 were females and 2142 were males. The average family size was 5.46 . Of the total population, 48.74 percent of the rural poor lived at Panchami and 28.02 percent and 23.24 percent lived at Amarpur and Nagi respectively. All the wards of Panchami VDC were covered for the study. Therefore, the number rural poor is the highest in Panchami.

The data for the study were gathered using sociological/anthropological and participatory techniques. In the first stage, rural poor households were identified by using well being ranking. The households which were ranked as the lowest were considered as rural poor and were taken for the in-depth study. Gender analysis tools, formal and informal interview, focus groups discussion and case study method were used to generate the information. In addition to these, continuous consultations were made with male and female about the gender relations in the poor households. A series of observations were made in both poor and well-off households to find out the classbased gender roles. Likewise, settlement-wise focus group discussions were held which had yielded numerous benefits to understand the male-female position in the poor households.

\section{The Rural Poor Households}

In this article, rural poor is used as a relative term. Food sufficiency and land holding size were the major indicators to distinguish the well-off and poor households. The rural poor have less than 15 ropanis of upland. The average farm size is 8.41 ropani. They produce little food and get involved in wage labour for survival. The food sufficiency is for less than six months. Therefore, they largely depend on agricultural and nonagriculture wage labour. Low productivity, insufficient food, inferior quality of livestock, indebtedness, small houses which are insufficient for sitting and sleeping, lack of oxen, small size of landholding, relatively large family size, lack of technical skill, no service holder in the family, etc., were the major socioeconomic characteristics of the rural poor.

There is some sort of co-operation between and among the caste, ethnic groups and classes during the time of natural calamities, hardship, etc. Cross-cultural and intercaste marriages have began to occur in the study area. There are several instances of Limbu and Briahmin, Limbu and Rai, Limbu and Majhi, Rai and Shepra cross-cultural marriages.

It was observed that the cultural norms and religious values have influenced the economic behaviour of the poor. To celebrate the fairs and festivals they sell their animals and property. They even mortgage their land and take loan to perform the death anniversary and marriage ceremony.

Parma is a non-formal labour organization of both welloff and poor households. It is based on reciprocal exchange of labour among the community members during peak agricultural seasons to prepare fields for sowing and later for transplanting for the crops. Generally, high level well-off families hire the labour during agricultural reason. But, some well-off and poor rely on Parma. In the study area Parma organization form the basis of neighbourhood. The Parmas is mainly determined by geographical proximity and kinship. The rural poor prefer wage labour to Parma because they have small piece of land which requires small number of labourers.

Many rural poor cultivate the land as share-cropper or lease-holder. The share croppers have to pay fifty percent of the production to the owners. Those who cultivate the rented-in land should pay fixed quantity of crops which is determined by two parties. In the study area, the share-cropper does not claim tenancy right due to the social relationship. If landlord is not satisfied, he may change the tenant. In case of share-cropping, the landlord has to share the seeds and peasant uses his muscle for production. In case of lease-holding the lease-holder is obliged to pay fixed quantity of grains regardless of the crop failure. If the relationship is good between the landlord and peasant landlord can provide his oxen to the tenant during cultivation. 
Some of the rural poor keep their children at well off homes as domestic servants. This tie makes food availability at poor households during the time of stress.

In the study area, the well-off and the poor have some sort of social tie. The poor receive loan from the rich people during the time of hardship or stress. The loan may be in cash or kind. The interest rate of the loan depends upon the relation between the poor and the rich. It was reported that when there is food stress or famine, the poor ask for food grains from the welloff. In this case, well-off people provide some inferior quality of grains free of cost. If the relationship in very close between the well off and the poor, the former provide meals to the latter for a couple of days during the time of hardship. In return, the poor provide short term free labours when well-off households require. Sometimes, the women of poor households have to wash utensils during fairs and festivals. In lieu of their services, the poor women are provided rice and some grains.

\section{Women in Rich and Poor Households}

The women of the poor households have double roles at the same time. They are involved in both household chores and wage earning activities. However, most of the women of welloff family are mainly engaged in housewives' roles. Some of the daughters and sisters of the rich family have jobs such as school teachers, social workers and the like. Both boys and girls from the well-off families get chance to go to school. On the contrary, very few cases of school enrolment are found among the poor families. Because of reading and writing skills of the well-off families, the local level government and semi-government jobs fall in their hands. Not only does this skill help to get the job for them at the local level but it helps to keep the poor in subordination position.

Both rich and poor women in the study areas are involved in agricultural works and households works such as digging, fetching water, collecting firewood, etc. Unlike poor women, the rich women do not carry the load in public places (markets) because of their social status. Sometimes, women of the well-off families go to market to sell agricultural commodities and vegetable foods. In this case, they make the poor to carry the load of the commodities to be sold.

Except few service holders, all of the women of well-off families make no contribution to cash income. On the contrary, the poor women earn something in cash or kind through wage labour. The poor women can use their earning to buy personal items (bangle, tika, tobacco, cigarettes, etc.) without their husband's consent. However, they are forced to consume their income to buy food-stuff. In the well-off families, whatever the decisions are made by the males are accepted by the women. In course of field visit, a woman reported that she hardly knew her husband's decisions after a long period of times. Unlike rich families, the poor families' decisions are open not only within family but also in the community. Because a poor should explain every-thing and his future strategy before getting the loan from the local money lenders.

In the study areas, recently some development activities like drinking water, irrigation canal, income generation program, health awareness program and non-formal education program have been started through the NGOs, INGOs, VDC and DDC. These organizations have provided local level job opportunities to some of the well-off women who have possessed required level of education. The employed women involved to mobilize the women as well as poor women are through the participatory approach. The poor women could not get involved in such development activities because of their hand to mouth problems. They feel lucky if they get a few days wage labour job within the village rather than to participate in such development activities.

Sometimes, female-related jobs and scholarships come to villages. These opportunities mostly go to the hand of well-off families. The well-off families not only use the power to control the poor but also use their capacity to grab new opportunities available at the local as well as national levels.

\section{Division of Labour}

In every society, there is some sort of division of labour between and among the male and female. A division of labour by sex exists among rural poor households. In the poor households, 
ploughing, roofing, climbing the trees to lop the fodder, threshing rice, sowing, making bamboo baskets and bamboo mattress, manufacturing agricultural implements, etc. are the major tasks of the males whereas transplanting millet and paddy, grinding maize and millet, husking and winnowing of crops, cooking rice and washing utensils are the female's works. Digging, wedding, harvesting and carrying load are common for both sexes.

Mothers usually nurse the infants. Mothers have major role for infants' caring which is also supported by grandmother and sister. If there are older children, the role of infant caring is also their role. If there are no grandmother and older children at home, the mother carries the infant at the back or puts the baby in the cradle during working time. Sometimes mothers leave their infants at neighbours' house if there are no persons to look after them at home. After two years of age, the children of poor houses receive very little care and attention. However, in well off household, children are cared properly up to five years. If males have leisure time and female is busy, the males also care the baby. It was observed that some males attended the community level meeting with children wrapped up in a shoulder.

As mentioned above in the poor households, food is always scarce. They fulfill their food demand hardly 0-6 months from own production. Therefore, they are always seeking wage labour within and outside of the village. Both male and female get wage labour job during the plantation and harvesting time of the crops. Males get job for cardamom farming, too. In the village, wages are not the same for all workers and works. Adolescent and women receive lower wages than adult men. Carrying big load, ploughing, roofing and mason work generate high wages than digging, rice planting and harvesting. Males charge more wages than females for the same type of works. Therefore, the employers prefers female workers in digging, harvesting and transplanting because of low wages.

For winter crops, females are involved more than males. During this time, labour opportunity is scarce within the village. Hence, most of the males go outside of the district to seek labour opportunity. Usually, males migrate in the month of Nov/Dec and come back in April/May. Women workload is increased during the time of male seasonal migration,. They have to devote their time to sowing, weeding and harvesting of the winter crops. Generally, the rural poor have no oxen. Therefore, they hire oxen along with plough man. For summer crops, they hire oxen only and males, plough the land. In the case of winter, both oxen and plough man should be hired. Usually, the poor households can not pay the charge of oxen. Therefore, they exchange their labour services for the oxen owners. In the study area, one should pay two male labourer or three female labourers for one pair of oxen power a day. Very little women migration was found during the field visit. The women of the poor households sometimes get the job of grinding, flouring, husking and cleaning vessels at the well-off households.

Two modes of payment are found in the study area. Generally, women workers would like to take grain or agricultural produce in lieu of their service. But males generally get their payment in cash.

In the study households, there is relatively small amount of grinding and flouring work because of low amount of food production. When they earn some money through wage labour, they buy ready made rice, maize and flour. Likewise, they have few utensils for cooking and eating. Little attention is paid for washing utensils and cloths. They wear the same clothes until they are worn out. Then others are made or bought. Unlike welloff, they perform their rituals and rites in short cut manner due to lack money. However, they have to spend some money for death and marriage celebration. Most of the Brahmins and Chhetris of the poor households gave up to observe the death anniversary but such type of practices are still prevalent among well-off households. Field observation shows that the women of well-off households are more involved in household chores,, ritualistic practices than poor women.

Similarly, the women of well-off households pay more attention to their husbands in comparison to poor women. In the poor households, gender roles are little bit flexible than in welloff households. During the field visit, men were observed fetching water, washing clothes, grinding com and doing many 
other household activities. In some cases, females are involved in the male-related job, too. In this regard, here is one interesting case study taken from Amarpur VDC.

Manmaya Majhi, a permanent resident of ward nine,
Amarpuur VDC of Panchthar district, is 39 years old. She
has a husband, one daughter and three sons. Her family has
three ropanis of upland. The production from the land is
hardly sufficient for three months. Manmaya was born in a
Majhi family. She got married to a Limbu family. Because
of cross-cultural marriage, she could not live along with her
mother-in-law. She was separated from her mother's-in-law
along her husband. She made a small hut in the village. For
the survival of the family, she began to saw wood. She
sawed the wood within and outside the district with male
partners. Usually, she operates the saw by sitting on saw-pit.
She aims to join NFE class but due to time constraint, she
has not joined yet. When she heard about family planning
devices, she began to use Depo-Provera. Now she advises
her colleagues to use the family planning devices. In course
of discussion, she said that she was interested to provide a
good education to her children so that they would not have
to face the hardship their mother was facing.

In the study households, some flexibility was observed with respect to male female division of labour. Because of poverty, both of them have sub-ordinate position in the society. In the same case, discrimination is created by outsiders. Below is a case from Nogi VDC of Panchther district.

The people of the poor households of Nagi have bad remarks about the health assistant of Tharu VDC's sub-health post. During the discussion, it was reported that the fee for the health assistant for delivery case depends upon the sex of the child. He claims Rs. 1500 to Rs. 2500 for male child born and Rs. 500 to Rs. 1000 for female child born.

The above discussion shows that women of the rural poor households also earn cash or kind through their labour. Flexible gender roles are found at the poor households. In the case of vulnerable houses, both male and female should go for wage earning throughout the year. They live in the state of deprivation, weakness and isolation. In such a case, division of labour is less significant than their survival.

\section{Daily Work Routine}

The present study has tried to get an idea of the activities of male and female do during one day in poor households. This information was collected in all ethnic and caste groups. There are some similarities in daily work routine between and among the caste and ethnic groups. Usually, both male and female start their work at six o'clock. However, wake up time varies from one household to another. Generally, all family members get up between 5 and 6 o'clock.

\section{Daily Routine of Female and Children}

Women's routine starts from fetching water and then they sweep the house. They begin to prepare meal around seven o'clock. If it is a joint family, mother-in-law prepares morning food and daughter-in-law collects fodder and firewood in the morning. If there are the oldest children, they also help in collecting fodder and firewood and then come back at nine o'clock. Women prepare meal up to ten o'clock. After the morning meal, women clean utensils, vessels and go for outside work. If there are school going children, they go to school at 9:30 and come back around 4:30. Although, most of the children of poor households drop out from school after completing three class. The enrolment of poor children in the primary schools is reported as being low. In primary education the enrollment of both boys and girls is more or less the same but higher number of girls were reported dropping out during primary school than boys. This is probably due to female responsibility for domestic chores inside the house and an attitude that education is at little value for women who are destined to marry and raise children in their husband's households. Almost all boys, too, drop out after completing primary education. When they are 9-10 years, they often go with their fathers for wage labour or portering. Some boys of the same age group work as domestic servants in the well-off houses. Those children who do not go to school either go for animal herding or assist their parents. If females go for wage labour, they come back around six o'clock at the evening. 
Those who have the oldest children, the children start to cook evening food. When their mother comes she handles kitchen works and children become free. Usually, evening meal is ready around seven to eight o'clock. After washing utensils, women go to bed at 9.30 p.m. Males go to the bed little bit earlier than females.

\section{Male Daily Routine}

As mentioned above, most of the males of the poor households migrate seasonally for six months of a year. When they stay at home, they start their work at six o'clock. If they have milking cow, they get up earlier than others.

At the community level, males play significant role than females. Males are considered as the chiefs of the family. If children and women make some mistakes, males should be responsible for their mistake. Loan taking and giving is done through males. The money lenders give loan only to males. Community believes that only males can fulfil the commitments but females do not. In fact, males have direct control over his land and other property. Only males can keep the land in mortgage. Similarly, the local shopkeepers do not give goods on credit to the females without consensus of the male partners. In this regard, a case study has been taken from Nagi VDC.

Ram Hari Giri is a permanent resident of Nagi VDC. He is
42 years old. He has a grocery shop at the village. He
supplies goods, clothes and other items. He sells both in
cash and on credit. He does not give the goods in credit to
the females without consensus of the males. He says that
the dealing with females and children is not fair. Because
they do not earn cash. If their male partner deny to pay the
loan he would in a great loss.

Similarly, the decisions of the males are considered more important than that of the female at community level works. If a woman takes some decision for community level work, the other community members ask again to the husband for final decision.. Males prepare food stuff for cattle, milk the cow, clear the cowshed and shift the animals at open space. The children provide fodder to cattle. If males have no morning duty, then they visit the well-off houses and get a cup of tea. In lieu of tea they helps in shifting cattle at open space, splitting $\log$, and providing fodder to cattle at well-off house. This kind of relationship makes sure to the rural poor to get loan from well-off at the time of hardship and food scarcity. Around nine o'clock a man comes back at home and then takes meal. After morning food, male leave for work. Males usually come back at five o' clock at the evening

\section{Household Decision-Making Process}

Decision-making is not a matter of debate at poor households. Generally, decisions are made on the basis of consensus. Minor decisions like selling of poultry and buying small items are made by females too. But decisions of taking loan, marriage of sons and daughter are made by both males and females. Usually, females actively involve in the decisions of buying and selling of animals. But during the time of hardship, males play significant role than females. As discussed above most of the male of poor households rely heavily on selling their labour and working outside their communities in order to ensure food security. Therefore, males participate to a lesser extent in a day to day household decision making process. Assignment of daily work for children is largely made by women. Women send their children for work like fodder collection, firewood collection, fetching water, herding, etc. They also divide the workload to her children on the basis of their age. Borrowing of small items like salt, food-grains and other spices is done by the females. In the case of borrowing bigger amount of money and buying larger quantity of food-grains, decisions are jointly made.

In the study area, some development activities are recently started in the field of community forestry, drinking water and irrigation. This activities require voluntary labour. In this situation community seeks male decision on labour contribution. Some of this activities need the physical strength such as carrying big load, cutting rock, etc., are undertaken by males. Therefore, community would like to take the consensus of the males before the development works. The above discussions 
show that females can play significant role at household level but not at community level.

\section{Access and Control Over the Resources}

In the study households, there are some flexibility and autonomy of own's eamings. However, because of the deprivation, their work and earning is so important for survival. Usually, women do not eam cash income from their wage labour. They receive their wage in kind which is used for day to day survival. Males, generally, receive their wages in cash which is used to pay loan, buy manufactured items (utensils, quit.), cloths, food, etc. Some of the poor households produce cash crops (bean, pepper, grams, etc.) in very small amount and sell at local markets. But it is not excess of their needs. Such items are generally sold by women. Income from the selling is used to buy salt, oil seeds, spices etc. Some portion of income is used to buy bangles, ritual marks, and bracelets. Both males and females have equal excess to animals, land and other property but socially and legally, land is controlled by males. Women have access and control over the kitchen gardening. The men enjoy doing bamboo works such as basket-making and rope making. The women have more access and control over the ornaments. In the time of severe food scarcity, ornaments are also kept as collateral. However, without female's consensus, male can not do it. It was reported that in the absence of the male household head, the female members are given considerable power and have influence in the allocation of household income, labour and the surplus so as to manage the farm efficiency. In the poor households, the concept of pewapat got less importance, because the whole family has face economic hardship and stress. Except the land right, the women enjoy equal control over on the resources and there is not sharp variation between the male-female role play in the poor houses.

\section{Conclusions}

The past studies on gender conducted by both native and foreign scholars and researchers used mostly macro-level data to understand the male-female relations. They analyzed literacy level, age at marriage, life expectancy and some other socio- economic indicators to find out the male-female status. Likewise, the past studies were either based on quantitative data or confined to high caste groups such as the Brahmins and Chhetries. We can summarize their conclusions in the following points :

- Women work more than men.

- Women have no say in major decision-making.

- Women have no control over the property.

- Women have no equal access resources education, power etc.

- Women are in sub-ordination positions.

What they generalized is partially true. Because such studies visualized only the picture of well off and culturally dominant groups. In the poor family, there is no dispute and conflict with regard to the control of the resource and property. Unlike high class or well off groups, there is no hard and fast rule of gender role. In the poor households, both male and female have similar vulnerabilities, needs and crisis.

This study is based on the poor households of the mid-hills. The economy at the household is heavily dependent on wage labour. Males are the major actors of the outside wage labour. And females are responsible for household works and wage labour within the community. The traditional division of labour is more flexible in poor households. Females have little works in the household chores in comparison to the well-off women. But females of the poor household should take male's responsibility also during the time of male absence from the home. Overall work load of the females is higher than males. The concept of access and control over on resources has little importance in the poor household because the whole family is in a state of deprivation and poverty. Both male and female earnings are used for maintenance of the households.

\section{REFERENCES}

Archarya, Meena and Lynn, Bennett.

1981 The Status of Women in Nepal, Kathmandu CEDA.

Ember, $\mathrm{C}$ and Melvin Ember

1990 Anthropology, Prentice-Hall, Delhi. 
Haralumbus, M

1997 Sociology Theme and Perspectives, Oxford University Press, Delhi.

Kalpagam, U.

1994

Labour and Gender Surrival in Urban India, Sage Publications, New Delhi.

Keller, Fox Evelyn and Helen E. Lorgino

1996 Feminism and Science, Keller, Fox Evelyn and Helen E. Lorgino Oxford University Press, New York.

Lorber, Judith

1994 Paradoxes of Gender Yale University Press, New Haven and London.

Mair, Lucy

1999

An Introduction to Social Anthropology, Second Edition, Oxford University Press, Delhi.

Pathy, Jagannath

Anthropology of Development Demystifications and Relevance, Gain Publishing House, Delhi.

Seddon, David 1995

Nepal a State of Poverty, Vikas Publishing House Pvt. New Delhi.

Slayter, Barbara Thomas, Andrea

Lee Esser, M. Dale Shields 1993

Tools of Gender Analysis: A Guide to field Methods for Bringing Gender into Sustainable Resource Management, ECOGEN Research Project, International Development Program, Clark University.

Strishakti 1995

Women Development and Democracy, A Draft Report Presented to Danida.

\section{EXCLUSION, THE POLITICS OF LOCATION AND WOMEN'S PROPERTY RIGHTS DEBATES IN NEPAL: A DISCOURSE ANALYSIS OF POLITICAL ACTIVISM}

Youba Raj Luintel*

The issue of women's right to parental property had sparked much controversy since the Bill was first presented in parliament. Advocates of the Bill and women rights groups had taken out a series of demonstrations demanding early passage of the Bill. Activists had gone to the extent of chanting slogans inside the House of Representatives and were thrown out by security personnel. They had even dragged the then Speaker out of his car at Singhadurbar gate. Oplponents of the Bill have claimed that the country at present is not ready for such a move that would bring sisters into property disputes that traditionally is limited to brothers.

- A news report in The Kathmandu Post (September 7; 1999).

\section{The Context}

The relationship between gender and property ${ }^{1}$ is one of the gateways to understand the crux of women's subordination. Women's property status in any society is one critical issue deserving due attention in order to understand the specificities of gender relations in that particular setting. This is, therefore, one of the crucial political arenas of women's empowerment process

* Mr. Youba Raj Luintel is ther Lecturer in Sociology at the Central Department of Sociology/Anthropology, Tribhuvan University, Kirtipur, Kathmandu.

I would like to thank Dr. Saskia Wieringa and Dr. Brigitte Holzner for their comments on an earlier draft of this paper

1 The term "property" refers to all productive resources and assets that a man or woman requires for his/her existence, subsistence and wellbeing. In the agrarian economies of South Asia arable land is the most valued form of property for its economic as well as political and symbolic significance (Agarwal, 1999). In this paper, however, property has been defined in a broader perspective, so we do not focus only on land. 